\title{
RELATIVE PERFORMANCE OF ROOT AND SHOOT DEVELOPMENT IN ENSET AND EASTAFRICAN HIGHLAND BANANAS
}

\author{
G. BLOMME, G. SEBUWUFU ${ }^{1}$, TEMESGEN ADDIS ${ }^{2}$ and L. F. TURYAGYENDA \\ Bioversity Uganda, P. O. Box 24384, Kampala, Uganda \\ ${ }^{1}$ Crop Science Department, Makerere University P. O.Box 7062, Kampala, Uganda \\ ${ }^{2}$ Southern Agricultural Research Institute (SARI), Awassa Research Center, P. O. Box 06, Awassa, Ethiopia
}

\begin{abstract}
East African highland bananas and enset belong to the genera Musa and Ensete (Ensete ventricosum), respectively. The root, corm and shoot growth of field-established enset and East African highland banana cultivars was assessed. Banana and wild enset plants were assessed in Uganda, while domesticated enset plants were assessed in Ethiopia. Growth traits of the enset and banana mats in Uganda were recorded at flower emergence of the banana plant crop, while enset plants in Ethiopia were assessed at 4 and 5 years after planting. The results obtained in Uganda indicate that enset had a significantly $(\mathrm{P}<0.05)$ shorter and thicker pseudostem compared to banana. In addition, enset had a larger root system with thicker cord roots. Results further showed that young enset plants had a significantly lower shoot-root ratio compared to the bananas. The shoot-root ratio in enset is, however, clone dependent and increases with an increase in age. The results also showed that root density in enset sharply decreases with increasing soil depth.
\end{abstract}

Key Words: Ensete ventricosum, Ethiopia, shoot-root ratio, Uganda

\section{RÉSUMÉ}

Les bananas de montagne d'Afrique de l'Est appartiennent respectivement à l'espèce genera Musa, et Ensete (Ensete ventricosum), La croissance des racines, bulbes et rejetons de champ-établi d'enset et de cultivars de banane de montagne d'Afrique de l’Est, ont été évaluée. La banane et les plantes d'enset sauvages ont été évaluées en Ouganda, pendant que les plantes d'enset domestiqué ont été évaluées en Ethiopie. Les traits de croissance des tapis d'enset et banane en Ouganda ont été enregistrés à l'apparition de fleur de la récolte de plante de banane, pendant que les plantes d'enset en Ethiopie ont été évaluées à 4 et 5 ans après la plantation Les résultats obtenus en Ouganda indiquent que cet enset a eu significativement $(\mathrm{P}<0.05)$ pseudostem plus court et plus épais à comparer à la banane. Par ailleurs, enset a un plus grand système fondamental avec les racines de corde plus épaisses. Les résultats poussés ont montré que ces jeunes plantes d'enset ont une grande proportion des rejetons en comparaison avec celle des bananes. La proportion des rejetons de enset est cependant un clone dépendant des augmentations de l'âge. Les résultats ont montré aussi que la densité des racines de enset diminue avec l'augmentation de la profondeur du sol.

Mots Clés: Ensete ventricosum, Ethiopie, la proportion tire-fondamental, Ouganda

\section{INTRODUCTION}

The Musaceae family is subdivided into the genera Musa and Ensete (Simmonds, 1966). While the banana fruit is known worldwide, enset (Ensete ventricosum) is only cultivated in
Ethiopia where products processed from the corm and the pseudostem are a major source of food for more than 12 million people (Barker and Simmonds, 1953; Bezuneh and Feleke, 1966; Westphal, 1975; CSA, 1997). Whereas the banana fruit is harvested within a relatively short period 
of less than 2 years after planting (YAP), enset is usually harvested at the end of the vegetative stage between 5-7 YAP. The time to flower emergence in enset depends on climatic conditions, genotype and management level (Brandt et al., 1997). Enset corms and pseudostems are normally processed at 5-7 YAP.

The production of both banana and enset is constrained by a number of factors including pests and diseases, and reduced soil fertility. Enset, being monocarpic and thus unbranched, has proven to be firmly anchored in the soil and toppling of field-grown pre-flowering plants is a rare occurrence (Price, 1995). In contrast, banana whose lateral shoots are expected to add to the plants' stability, is more susceptible to toppling. The aim of this study was to compare; root, corm and shoot growth of field-established enset and East African highland bananas, and to get insight into the shoot-root ratio of banana and enset to better understand plant stability across the Musaceae family. This research could hence contribute to future banana and enset breeding work focussing on plant stability, shoot-root ratio and even research on plant response to nematode and weevil infestation.

\section{MATERIALS AND METHODS}

Wild Ugandan enset plants (Photo 1) and East African highland bananas (cultivars 'Siira' and 'Entaragaza') (Musa AAA-EA group) were planted and assessed at the Makerere University Agricultural Research Institute, Kabanyolo (MUARIK) located in Central Uganda ( $0^{\circ} 28^{\prime} \mathrm{N}$, $32^{\circ} 37^{\prime} \mathrm{E}, 1,150 \mathrm{~m}$ above sea level). The site has a mean annual rainfall of $1,300 \mathrm{~mm}$, which is bimodally distributed. The soils are classified as Eutric ferralsols according to the USDA (Yost and Estwaran, 1996). The trial site had been under a

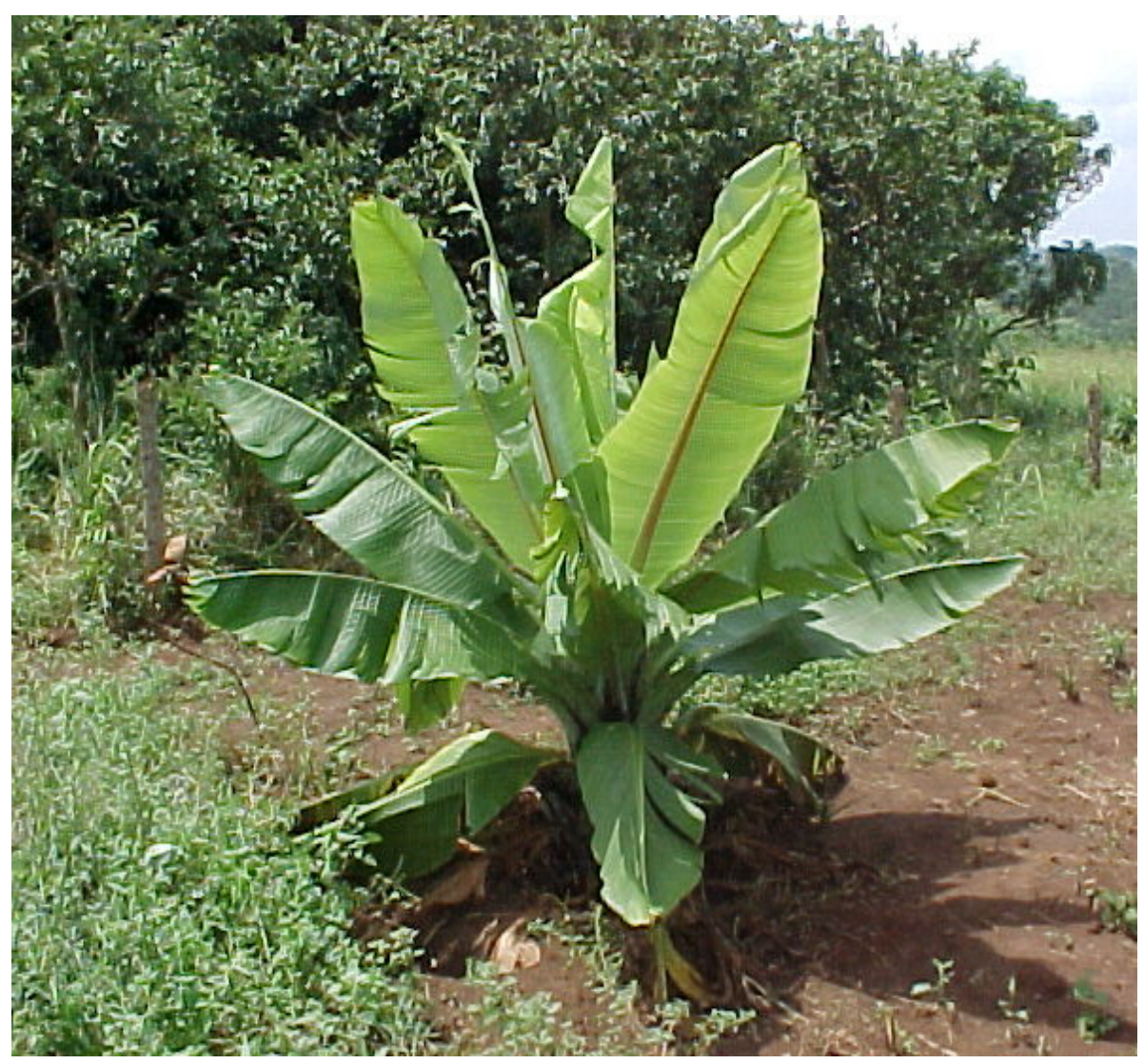

Photo 1. A16 months old wild enset plant assessed in Uganda. 
grass fallow for a period of 5 years and was manually prepared in order to avoid soil disturbance.

Seeds of wild enset plants were collected from a swampy area $30 \mathrm{~km}$ north of Kampala in Uganda. The seeds were soil planted. Subsequently, the young wild enset plants were raised in a nursery for 8 weeks before field establishment. The field layout was a randomised complete block design and plant spacing was $4 \mathrm{~m} \mathrm{x} 4 \mathrm{~m}$. The banana and enset plants were planted in holes $60 \mathrm{~cm}$ wide and $60 \mathrm{~cm}$ deep.

For the East African highland bananas, two types of banana planting materials were used: pared suckers and in vitro plantlets. Six plants per banana genotype and planting material type were used, while 14 enset plants were assessed. To control nematodes and weevils, $20 \mathrm{~g}$ of
Furadan was applied on the soil around the mat at planting and at 14 WAP. No irrigation was carried out.

In addition, two clones of domesticated enset ('Yeka' and 'Masha Gamo') were assessed at the Southern Agricultural Research Institute (SARI) research station in Awassa, southern Ethiopia ( $7^{0}$ $03^{\prime} \mathrm{N}, 38^{0} 30^{\prime} \mathrm{E}, 1,700 \mathrm{~m}$ above sea level). The site has a mean annual rainfall of $1,046 \mathrm{~mm}$, which is bi-modally distributed. The soils are classified as Eutric nitosols according to the USDA (Ethiopian Mapping Authority, 1988; Yost and Estwaran, 1996).

One year old plants of both enset clones were field established. Five plants per clone were assessed at 4 YAP, while an additional 2 plants per clone were assessed at flower emergence [5 YAP] (Photo 2). In Ethiopia, the enset plants were

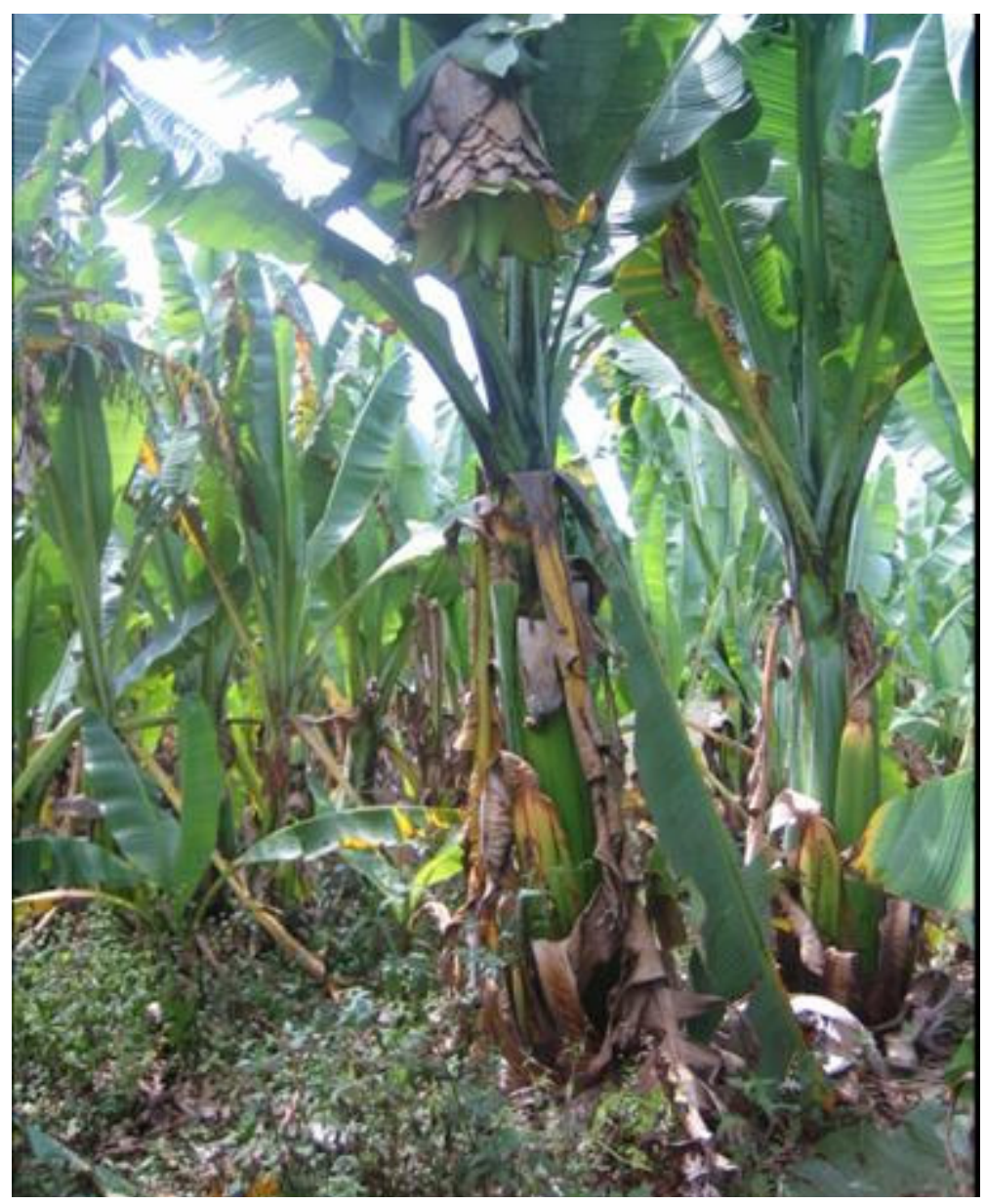

Photo 2. A flowering 5 year old 'Mashagamo' enset plant assessed in Ethiopia. 
planted in holes with a diameter and depth of 30 $\mathrm{cm}$, at a spacing of $2 \mathrm{~m}$ between rows and $1.5 \mathrm{~m}$ between plants in a row.

Pesticides and chemical fertilisers were not applied. However, a single application of $0.5 \mathrm{~kg}$ composted manure was applied per plant at three months after planting. The plants were not irrigated. Regular weeding was carried out and old enset leaves were regularly pruned.

In Uganda, growth traits of the wild enset plants and banana mats (i.e. mother plant and lateral shoots) were recorded at flower emergence of the banana crop (i.e. 1.3 YAP), while 4 and 5 year old domesticated enset plants were assessed in Ethiopia.

Data were taken on shoot and root growth. The shoot parameters measured included plant height $(\mathrm{PH})$, circumference of the pseudostem at soil level (PC) and leaf area (LA). Leaf length and leaf widest width were measured and LA was calculated according to Obiefuna and Ndubizu (1979). Leaf dry weight (LW) and pseudostem dry weight (PSW) were also recorded.

The plants were completely excavated and the following corm and root data was collected: corm dry weight (CW) number of adventitious or cord roots (NR), cord root length (LR), average diameter at the base of the cord roots (AD) and root dry weight (RW). Cord root length was measured using the line intersect method (Tennant, 1975), while the diameter of the cord roots was measured with a Vernier Caliper. The shoot-root ratio was calculated as the ratio of leaf, pseudostem and corm dry weight over root dry weight. In addition, root distribution down the soil profile was also assessed on one 4 year old Yeka' and one 4 year old 'Masha Gamo' enset plant in Ethiopia. Data were subjected to analysis using the Microsoft Excel and SAS (SAS, 1999) computer packages.

\section{RESULTS AND DISCUSSION}

The results obtained in Uganda indicate that at 1.3 YAP enset had invested more in leaf biomass and had a significantly $(\mathrm{P}<0.05)$ shorter and thicker pseudostem compared to bananas (Table 1). In addition, enset had a larger root system with thicker cord roots (Table 1). Results further showed that the corms of enset plants had a similar weight with the banana corms (Table 1). However, enset plants had a significantly lower shoot-root dry weight ratio than the bananas (Table 1). The lower shoot-root ratio probably indicates that young enset plants partition more assimilates towards root growth compared to bananas. This may be one of the reasons why enset has enhanced plant stability. In addition, the thick cord roots of the enset plants may enhance the plant's tolerance to nematodes and may enhance the plants anchorage strength.

The number of cord roots for the in vitroderived Entaragaza plants and enset did not differ significantly (Table 1). The number of banana roots varies considerably depending upon the health status of the plant. A healthy corm of a mature plant can bear 200 to 300 primary cord roots with a total length of $230 \mathrm{~m}$ (Robin and Champion, 1962; Beugnon and Champion, 1966). However, a banana mat (i.e. mother plant and lateral shoots) at flowering of the mother plant can have over 600 cord roots (Blomme, 2000).

During the final stages of vegetative growth, the enset root system size stagnates or even decreases (Table 2). This may be partially linked to the observed 'high mat' phenomenon, whereby the corm and newly formed roots progressively grow above soil level. There is a clear increase in the enset shoot-root ratio with increasing age (Tables 1 and 2). This is in agreement with observations made for banana (Blomme, 2000). The enset shoot-root ratio also depends on the clone (Table 2). This is in contrast to observations made by Blomme (2000) on banana where similar shoot-root ratios were observed for the mats of several genotypes.

The root distribution down the soil profile assessed on 4- year old domesticated enset plants showed that the root density decreases with increasing soil depth (Fig. 1). About 89 and $96 \%$ of cord roots of, respectively, 'Yeka' and 'Mashagamo' plants were found within the upper $40 \mathrm{~cm}$ soil layer. Similarly, enset root system assessment conducted at Yirgachefe in southern Ethiopia (6012'N, 38 ${ }^{0} 12^{\prime}$ 'E, 1,847 $\mathrm{m}$ above sea level) on 2 year old 'Genticha' plants showed that $96 \%$ of the cord roots were found within the upper 40 cm soil layer (Addis, 2005). 
Root and shoot development in enset and East African highland bananas

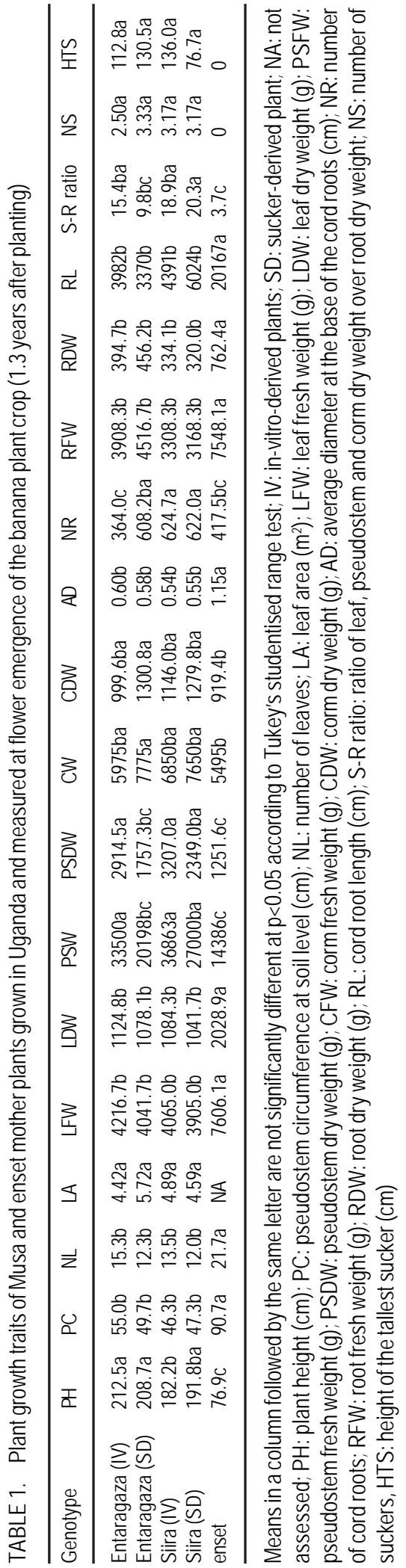

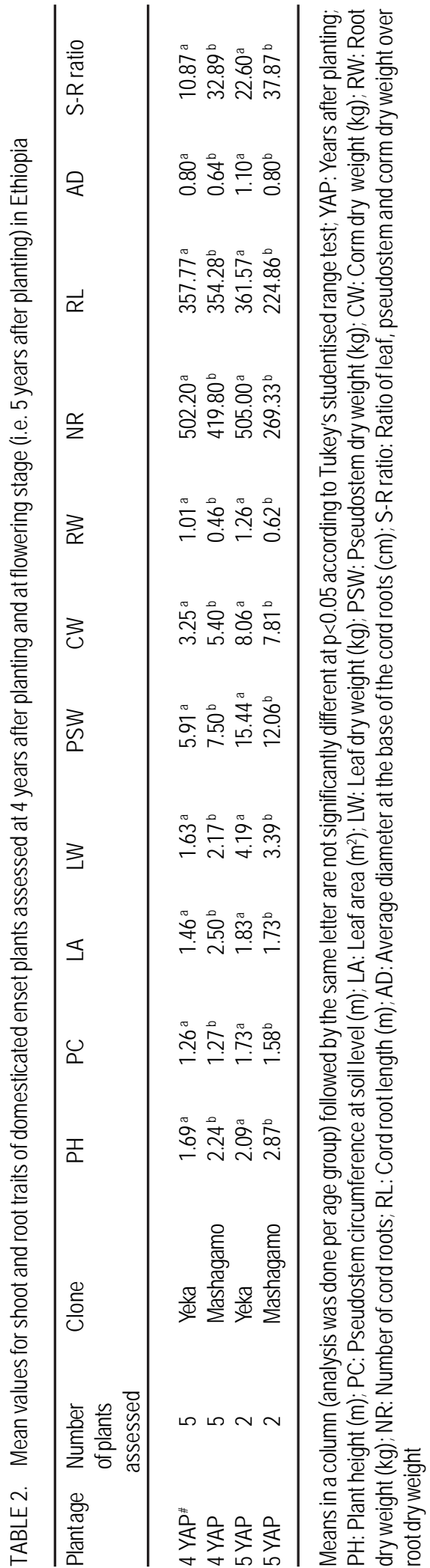




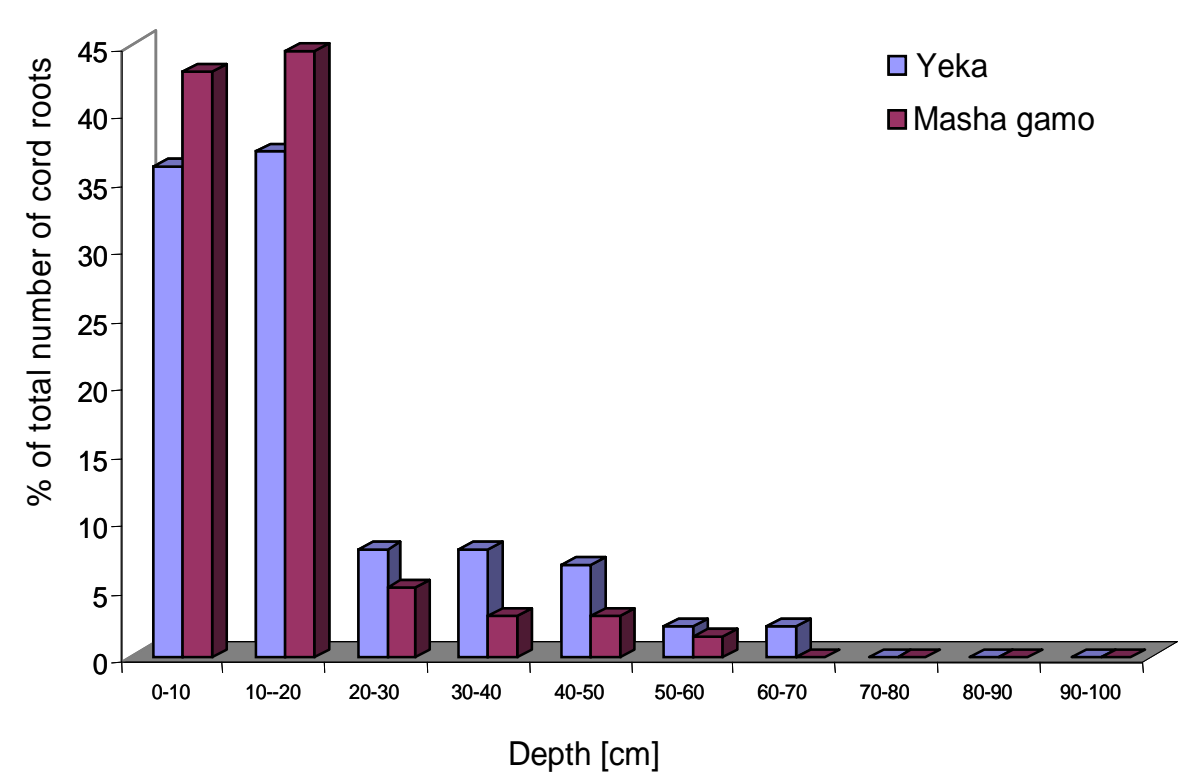

Figure 1. Distribution of enset roots down the soil profile for 4 year old plants of the clones 'Yeka' and 'Mashagamo' assessed in Ethiopia.

\section{ACKNOWLEDGEMENTS}

Financial support from Bioversity International, the Rockefeller foundation and the Flemish Association for Development Cooperation and Technical Assistance (V.V.O.B., Belgium) is gratefully acknowledged.

\section{REFERENCES}

Addis, T. 2005. Biology of enset root mealybug (Cataenococcus ensete) Williams and MatileFerrero (Homoptera: Pseudococcidae) and its geographical distribution in southern Ethiopia. M. Sc. Thesis. Alemaya University, Ethiopia. pp. 81.

Barker, R.E.D. and Simmonds, N.W. 1953. The genus Enset in Africa. Kew Bulletin 3:405416.

Beugnon, M. and Champion, J. 1966. Etude sur les racines du bananier. Fruits 21: 309-327.

Bezuneh, T. and Feleke, A. 1966. The production and utilization of the genus enset in Ethiopia. Economic botany 20:65-70.

Blomme, G. 2000. The interdependence of root and shoot development in banana (Musa spp.) under field conditions and the influence of different biophysical factors on this relationship. Ph.D. thesis $\mathrm{N}^{\circ}$ 421. K.U.Leuven. Faculty of Agriculture and Applied Biological Sciences. Belgium. pp. 183.

Brandt, S. A., Anita, S., Clifton, H., Terrence, M.C. J., Endale, T., Mulugeta, D., Gizachew, W. M, Gebre Y., Masyoshi, S. and Shiferaw, T. 1997. The "Tree against Hunger": Enset- based agricultural systems in Ethiopia. American Association for the Advancement of Science, Washington, DC, USA. pp. 56.

CSA, (Central Statistical Authority), 1997. Area, production and yield of crops of private holdings in 1996/97 in Meher season. Addis Ababa, Ethiopia.

Ethiopian Mapping Authority. 1988. National Atlas of Ethiopia. Addis Ababa, Ethiopia. pp. 76.

Obiefuna, J.C. and Ndubizu, T.O.C. 1979. Estimating leaf area of plantain. Scientia Horticulturae 11: 31-36.

Price, N.S. 1995. Banana morphology, part 1: roots and rhizomes. In: S. Gowen (Ed.), pp.190-205. Bananas and Plantains, Chapman and Hall. 
Robin, J. and Champion, J. 1962. Etudes des émissions des racines de la variété du bananier Poyo. Fruits 17: 93-94.

SAS institute. 1999. SAS Institute Release 8.2 Inc., Cary, NC, USA.

Simmonds, N.W. 1966. Bananas. 2nd ed. Longman, London and New York.

Tennant, D. 1975. A test of a modified line intersect method for estimating root length. Journal of Ecology 63: 995-1001.
Westphal, E. 1975. Agricultural system in Ethiopia, Center for Agricultural Publishing and Documentation, Wageningen. pp 14.

Yost, D., and H. Estwaran. 1996. Major Land Resource Areas of Uganda. World Soil Resources, Soil Conservation Service, USDA, Washington D.C. 